\title{
嬩下機能からみた骨棘形成と咽喉頭異常感との関連
}

\author{
防衛医科大学校耳鼻咽喉科学教室（主任：井上鐵三教授） \\ 大 前 由紀雄, 井上 鐵 三, 北 原哲

\section{RELATIONSHIP BETWEEN CERVICAL OSTEOPHYTES AND GLOBUS SENSATION — A STUDY BASED ON ALTERED SWALLOWING FUNCTION —-}

\author{
YUKIO OHMAE, M.D., TETUZO INOUYE, M.D. and SATOSHI KITAHARA, M.D.
}

\author{
Department of Otolaryngology, National Defense Medical College, Saitama
}

The swallowing function of ten patients showing marked cervical osteophytes were studied by double contrast pharyngogram and manometric examinations. In five cases in which the pharyngeal clearance was B type according to Shuzaki's classification, a significant increase in the maximal swallowing pressure value on the oral side ipsilateral to the osteophytes was often observed. In five cases in which the pharyngeal clearance showed $A+A^{\prime}$ type (marked impairment), the frequency of significantly decreased maximal swallowing pressure on the oral side ipsilateral to the osteophytes and abnormal waveforms of the swallowing pressure were high. However, no definite correlation was noted between these changes in swallowing function and osteophytesite.

Therefore, there are two possible outcomes of the changes in swallowing function caused by cervical osteophytes: one is a compensatory increase in pharyngeal constriction aimed at maintaining relatively good pharyngeal clearance, the other is impaired pharyngeal constriction and the pharyngeal clearance. These changes in swallowing function would impact on globus sensation.

Key words : 骨棘, 咽喉頭異常感, 與下障害, 咽頭二重造影検查, 㖟下压検査

A $96-0379-50422$

\section{1. 緒言}

背椎椎体前縁に形成される異常骨增殖（以下骨棘と 記す）屾，春椎の中でも頸椎に好発し咽喉頭異常感，

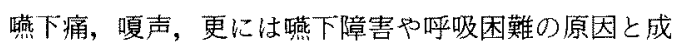
り得ることが報告されている1.こうした骨棘形成を 認める疾患としては，变形性顓椎症，強直性勒带骨化 症 (Forestier 病), 強直性脊椎炎, 外傷後の骨新生, 先天性骨棘などが上げられる。この内 Forestier 病は, 嚥下障害を呈する疾患の1つとして広く耳鼻㸶喉科領 域で知られているが，嗌下障害を訴える重症例注まれ である。しかし，德下障害を呈する以前に咽堠頭異常 感（以下異常感と記す）を自賞していることがほとん
どであったり2)，異常感を訴える症例の10-40\%にX線 学的な頸椎異常を認めると報告されている゙?. 従って, 骨棘が䁩下機能になんらかの影響を与えている可能性 が示唆されるが, 曣下障害を呈した重症例以外の矌下 機能はほとんど検討されていない。そこで, 著者らは， 異常感以外に明らかな症状を認めなかった症例のう ち，X線学的に骨棘形成が著明であった10例を対象と

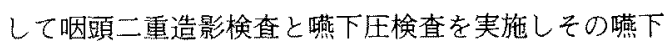
機能に関して考察してみた。

\section{2. 対象}

1988年 4 月から 1991 年 3 月の間に咽喉頭異常感を主 
訴に防衛医科大学校病院耳鼻咽院科外来を受診した症 例のうち, 食道造影検查で著明な骨棘以外に器質的な 異常を認めなかった10例を対象とした。著者ら注，骨 棘の程度をNathanによる分類)を基にして4 段階に 分け（表 1) 検討しているが，今回は，鳥の嘴状の骨 輠で近接する椎体の骨棘同士が接する stage III と，近 接した椎体の骨棘同士が互いに融合して架橋状になっ た stage IVを著明な骨棘を認める症例とした。

対象の内訳は, 年龄55歳から89歳で, 男性 7例, 女 性 3 例の計10例であった，骨棘の程度は，stage III 5 例, stage IV 5 例で, 骨棘の形成部位は, 第 4-6 頸椎 間に骨棘を認めたのが 2 例, 第 4-7 頸椎間 1 例, 第 5 - 6 頸椎間 4 例，第 5-7 頸椎間 3 例であった. 症状と しては, 全例, 空㖟下時の咽㮢頭異常感を訴えていた。 今回の対象で注自覚的な嬩下障害や誤噮の訴えを認め なかったが, 食道造影検查でわずかながら造影剂の気 管内流入を認めた症例が stage IVで 3 例認められた。 なお対象症例の一覧を表 2 に示した。

\section{3. 方法}

嚥下機能の評価に注，咽頭二重造影検査と磺下圧検 查を実施した。

咽頭二重造影検査では, 須崎の方法に従って咽頭ク リアランス能を検討しだ) まず140\%硫酸バリウムを 約 15-20ml（いわわる1口）嚥下させ睘下動態を観察し たのち，3回の空睜下を繰り返しその後に撮影した二 重造影像より 3 タイプに分類した。すなわち，バリウ 么の連続的付着と構造描出を認める $\mathrm{A}^{\prime}$ タイプと連続 的付着を認める $\mathrm{A}$ 夕イプを合わせて $\mathrm{A}+\mathrm{A}^{\prime}$ タイプ, 不連続的付着を認めるB夕イプ,きれいにpush outさ れるCタイプとした.

曣下圧検査は, $2.5 \mathrm{~cm}$ 間隔に 4 センサーを設置した ゲールテック社製圧トランスデューサーを使用し，食 道入口部の静止圧値, 並びに各部位の最大圜下圧（P 波）值や異常酸下圧波形の有無を検討した。測定部位 は，X線側面透視下に最も尾側のセンサーが第 6 頸椎 中部（食道入口部に相当）に位置するよう固定し, 頭 側に $2.5 \mathrm{~cm}$ 問隔で設置したセンサーの位置をX 線側 面透視下に観察しながら背側方向の䠢下圧を 4 点同時 に測定した。得られた噯下圧波形は，日本電気三栄製 ポリグラム360システムに $50 \mathrm{~mm} / \mathrm{sec} て ゙$ 記録した。

な扔骨棘自体は，30歳代から認められはじめ軽微な 変化も含めると高歯者で極めて高頻度に認められる変 化であるため
表 1 骨棘の stage 分類 (Nathan の分類4)

stage I：孤立した点状の骨棘

stage II：椎体から水平方向に突出した骨棘

stageIII：鳥の嘴状の骨輠で，近接する椎体の骨棘同 士が接する

stageIV：近接する椎体の骨棘同士が療合し架橋状と なる

表 2 対象症例

\begin{tabular}{|c|c|c|c|c|c|}
\hline No & 年綀 & 性別 & 棘 & クリアランス & 誤德 \\
\hline 1 & 73 & M & C 5-7 stage IV & $A^{\prime}$ & + \\
\hline 2 & 89 & M & C 4-6 stage IV & $A^{\prime}$ & + \\
\hline 3 & 66 & M & C 4-6 stage IV & A & + \\
\hline 4 & 63 & M & C 4-7 stage IV & B & - \\
\hline 5 & 77 & F & C 5-7 stage IV & B & - \\
\hline 6 & 67 & M & C 5-7 stage III & $\mathrm{A}^{\prime}$ & - \\
\hline 7 & 56 & M & C 5-6 stage III & A & - \\
\hline 8 & 55 & M & C 5-6 stage III & $B$ & - \\
\hline 9 & 58 & $\mathrm{~F}$ & C 5-6 stage III & B & - \\
\hline 10 & 81 & $\mathrm{~F}$ & C 5-6 stage III & B & - \\
\hline
\end{tabular}

下機能になんら異常を認めない成人 15 名（年齢20歳か ら32墄，平均 24 墄）から得られた燕下压值をコントロ ールとした.

\section{4. 結 果 (表 3)}

1）咽頭二重造影検查の結果

骨棘が stage IVであった 5 例の内, $\mathrm{A}+\mathrm{A}^{\prime}$ タイブを 示したのは 3 例, B夕イプを示したのは 2 例であった。 また, stage IIIであった5 例の内, $\mathrm{A}+\mathrm{A}^{\prime}$ タイプを示 したのは 2 例，B夕イプを示したのは3例であった。 今回の対象症例では，Cタイプは1例もなく全例に咽 頭クリアランス能の低下を認めたが，骨棘の stage と 咽頭クリアランス能の間には明らかな相関を認めなか った.

2）睘下圧検查の結果

第 6 頸椎の部位で測定した食道入口部の静止圧は, stage IVを示した1例で有意に上昇していたが，他の 9 例では明らかな変化を認めなかった。

次に骨棘より頭側の部位におるける最大德下圧值の変 


\section{Swallow in Normal Subject}

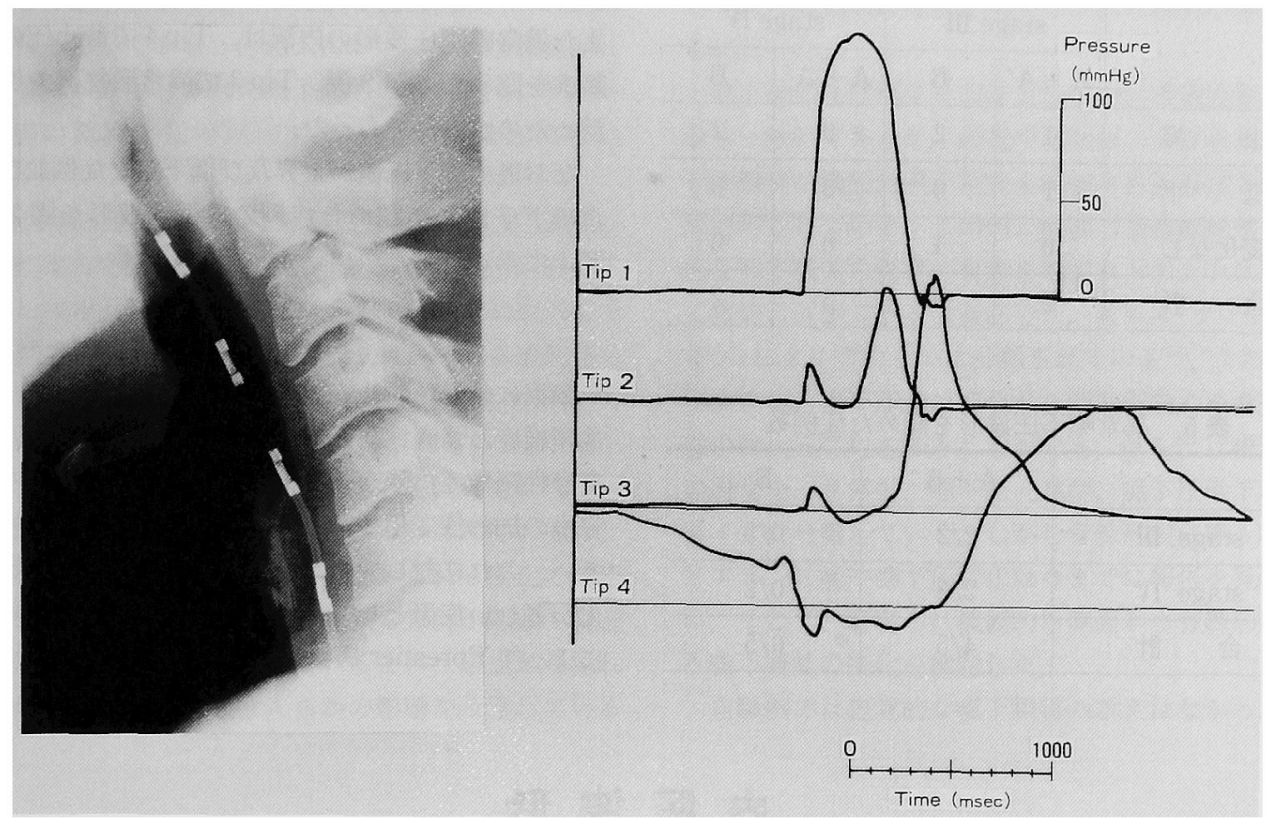

図 1 Tip の位置と正常例の噮下圧波形 （被検者は著者本人）

表 3 嚥下機能検査の結果

\begin{tabular}{|c|c|c|c|c|c|c|c|c|}
\hline \multirow{2}{*}{ No } & \multirow{2}{*}{$\begin{array}{l}\text { 骨棘の } \\
\text { stage }\end{array}$} & \multirow{2}{*}{$\begin{array}{l}\text { クリア } \\
\text { ランス }\end{array}$} & \multicolumn{4}{|c|}{ 噯下玨値（mmHg） } & \multirow{2}{*}{$\begin{array}{c}\text { 静止压 } \\
(\mathrm{mmHg})\end{array}$} & \multirow{2}{*}{$\begin{array}{l}\text { 異常波形 } \\
\text { の有無 }\end{array}$} \\
\hline & & & TIP 1 & TIP 2 & TIP 3 & TIP 4 & & \\
\hline 1 & stage IV & $A^{\prime}$ & $61 \pm 5^{*}$ & $51 \pm 11$ & $118 \pm 31$ & $128 \pm 27$ & $24 \pm 7$ & + \\
\hline 2 & stage IV & $A^{\prime}$ & $19 \pm 5^{*}$ & $35 \pm 17$ & $148 \pm 40$ & $109 \pm 32$ & $32 \pm 3$ & \\
\hline 3 & stage IV & A & $79 \pm 10$ & $75 \pm 4$ & $62 \pm 3^{*}$ & $89 \pm 30$ & $82 \pm 2^{*}$ & + \\
\hline 4 & stage IV & B & $171 \pm 8^{*}$ & $102 \pm 7^{*}$ & $72 \pm 2$ & $77 \pm 21$ & $26 \pm 4$ & \\
\hline 5 & stage IV & B & $142 \pm 25$ & $58 \pm 2$ & $263 \pm 33^{*}$ & $130 \pm 14$ & $28 \pm 1$ & \\
\hline 6 & stage III & $A^{\prime}$ & $102 \pm 4$ & $137 \pm 38^{*}$ & $76 \pm 10$ & $138 \pm 43$ & $23 \pm 4$ & + \\
\hline 7 & stage III & A & $74 \pm 14$ & $27 \pm 7^{*}$ & $111 \pm 6$ & $56 \pm 21$ & $27 \pm 5$ & + \\
\hline 8 & stage III & B & $94 \pm 8$ & $50 \pm 11$ & $106 \pm 14$ & $91 \pm 28$ & $27 \pm 2$ & \\
\hline 9 & stage III & B & $93 \pm 10$ & $166 \pm 40^{*}$ & $143 \pm 17$ & $141 \pm 15$ & $48 \pm 9$ & \\
\hline \multirow[t]{2}{*}{10} & stage III & B & $72 \pm 4$ & $151 \pm 63^{*}$ & $132 \pm 7$ & $82 \pm 28$ & $28 \pm 4$ & \\
\hline & \multicolumn{2}{|c|}{ 正常値 $(N=15)$} & $103 \pm 29$ & $58 \pm 19$ & $101 \pm 26$ & $104 \pm 28$ & $31 \pm 10$ & \\
\hline
\end{tabular}

$*: \mathrm{P}<0.01$

化を表 4 に示した。最大嚥下圧值が有意に上昇した症 例（ $\mathrm{P}<0.01 ： \mathrm{t}$ 検定）は stage III 3 例, stage IV 2 例の計 5 例で, この 5 例の咽頭クリアランス能は $\mathrm{A}+$ $\mathrm{A}^{\prime}$ タイプ 1 例, Bタイプ 4 例であった。逆に骨棘より
頭側における最大嚥下圧值が有意に低下した症例 （ $\mathrm{P}<0.01 ： \mathrm{t}$ 検定）は stage III 1 例, stage IV 3 例の 計 4 例で,この 4 例の咽頭クリアランス能は, 全例 $\mathrm{A}+$ $\mathrm{A}^{\prime}$ タイプを示した。異常嚥下圧波形を認めた症例は， 
表 4 最大嚥下压值（P波）の変化

\begin{tabular}{cc|c|c|c|c}
\hline \multirow{2}{*}{} & \multicolumn{2}{|c|}{ stage III } & \multicolumn{2}{c}{ stage IV } \\
\cline { 2 - 6 } & $\mathrm{A}+\mathrm{A}^{\prime}$ & $\mathrm{B}$ & $\mathrm{A}+\mathrm{A}^{\prime}$ & $\mathrm{B}$ \\
\hline \multicolumn{2}{c|}{ 上 } & 1 & 2 & 0 & 2 \\
\hline \multicolumn{2}{|c|}{ 低 } & 1 & 0 & 3 & 0 \\
\hline \multicolumn{2}{|c|}{ 変化なし } & 0 & 1 & 0 & 0 \\
\hline \multicolumn{2}{|c|}{ 合 計 } & 2 & 3 & 3 & 2 \\
\hline
\end{tabular}

表 5 異常臙下圧波形を認めた症例数

\begin{tabular}{c|c|c}
\hline & $\mathrm{A}+\mathrm{A}^{\prime}$ & $\mathrm{B}$ \\
\hline stage III & $2 / 2$ & $0 / 3$ \\
\hline stage IV & $2 / 3$ & $0 / 2$ \\
\hline 合 計 & $4 / 5$ & $0 / 5$ \\
\hline
\end{tabular}

stage III 1 例, stage IV 3 例の計 4 例で,この 4 例の咽 頭クリアランス能は全例 $\mathrm{A}+\mathrm{A}^{\prime}$ タイプであった(表 5). また異常嬹下圧波形の内訳は，Tip 4 で静止圧の低下 障害を認めたのが 3 例, Tip 3 で異常陽性波の出現を 認めたのが 1 例であった.

なお最大嶼下圧值が上昇及び低下した症例並びに異 常嶼下圧波形を認めた症例の曣下圧波形を図 2 から 図 4 に示した。

\section{5. 考察}

頸椎に骨棘を認める頻度が多い疾患としては, 変形 性頸椎症と強直性靶帯骨化症が知られている。この内, 変形性頸椎症に伴う骨棘は比較的高頻度に認められる 脊椎の加齢性変化で, 臨床的には全く無症状な場合も 多い。これに対して強直性䩲帯骨化症は, 前縦靶帯骨 化が著しい疾患として Forestier が報告し7), Lackner によって Forestier 病と呼ばれるようになった比較的

\section{内圧 波 形}
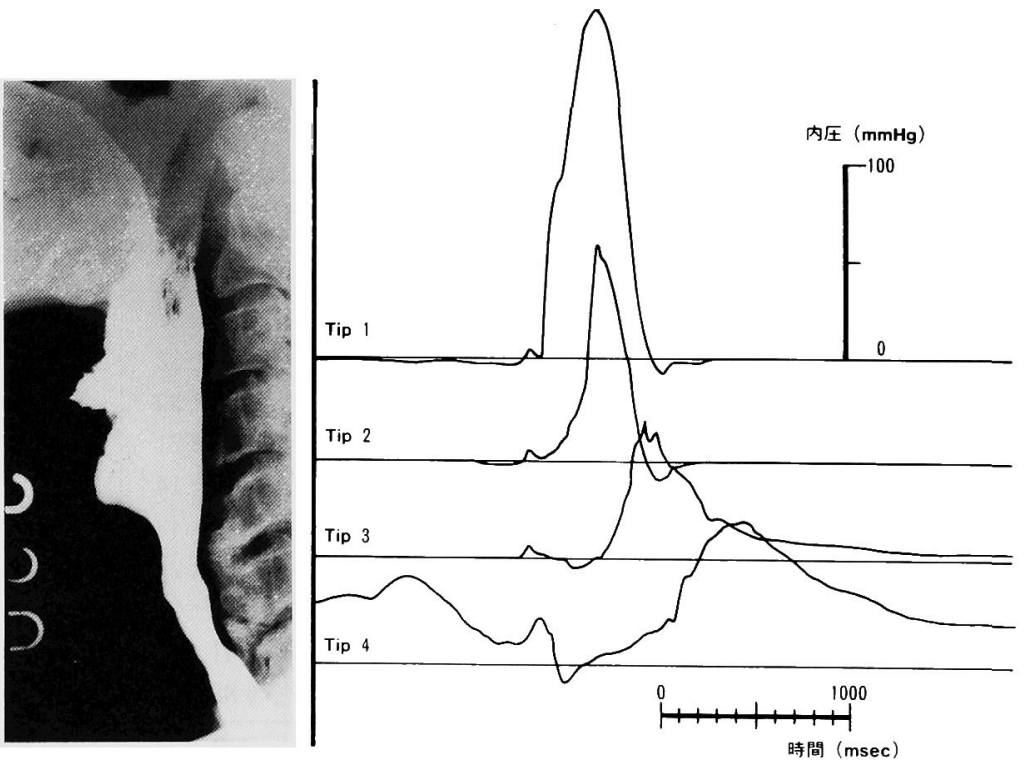

K.K. 63歳 男性

$\mathrm{C}_{4-7}$ Stage IV

図 2 症例 4 の燕下圧波形

咽頭クリアランスは須崎の分類で B タイプを示した。嚥下圧検査では

Tip 1 及び Tip 2 で最大舆下圧值の有意な上昇を認めた. 
まれな疾患である ${ }^{8)}$.こうした病態の差異から, 嬹下障 害などの臨床症状を呈する骨棘の報告例は, Forestier 病がほとんどであるし, 過去において変形性頸椎症に よる骨棘が原因とされた嬹下障害の報告例も，Forestier 病の認識不足が原因であったと指摘されてい $3^{9)}$.

Forestier 病に伴う睘下障害のメカニズムとしては, 骨棘による咽頭・食道腔の物理的な圧迫 ${ }^{10)}$ (14), 食道入 口部レベル（第 6 頸椎）など骨棘の解剖学的な形成部 位の関与 ${ }^{15)}$, 物理的刺激を基盤とした咽頭・食道周囲の

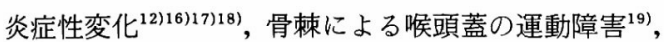
輪状咽頭筋の spasm $^{20)}$ などが報告されているが, 嚥下 障害を呈した重症例の報告例を除いて，骨棘に伴う嬩 下機能の変化に関してはほとんど検討されていない. しかし, 骨棘は比較的高頻度に認められる変化で, 程 度の差はあるにしても頸椎体前縁の骨棘が咽頭・食道 腔を後方から前方に圧排しているという観点から見れ ば，曣下機能に対してなんらかの影響を及ほしている
と考えられる，そこで，骨棘形成が明らかにもかかわ らず異常感以外の症状を認めなかった症例の曣下機能 を検討した。

噯下機能を評価する方法としては, 食道造影検査が 最も一般的であるが, 最近では咽頭二重造影検査や嬩 下圧検査が機能的嶼下障害を評価する検查法として臨 床応用されている。この内, 咽頭二重造影検査は潜在 的な嚥下機能の障害の有無を咽頭クリアランス能とし て簡便に評価できる検查法で21)，A+ $\mathrm{A}^{\prime}$ タイプ・ $\mathrm{B}$ タ イプ・Cタイプの 3 つに分類されている22) また, 嚥下 圧検查は，嬩下圧値の変化から咽頭収縮力や食道入口 部の静止圧変化を知ることができ, 森ら ${ }^{23)}$ は愼下圧値 の異常を, 正常型, 嚥下圧六進型, 嚥下圧低下型の 3 タイプに分類している.しかし骨棘形成に伴う咽頭ク リアランス能や䁩下圧変化は今までに報告を見ていな い. そこで, 著者らは機能的な側面から骨棘形成に伴 う嚥下機能の変化を検討した。

自験例では自覚的な嚥下障害の訴えはなかったが,

\section{内圧波形}

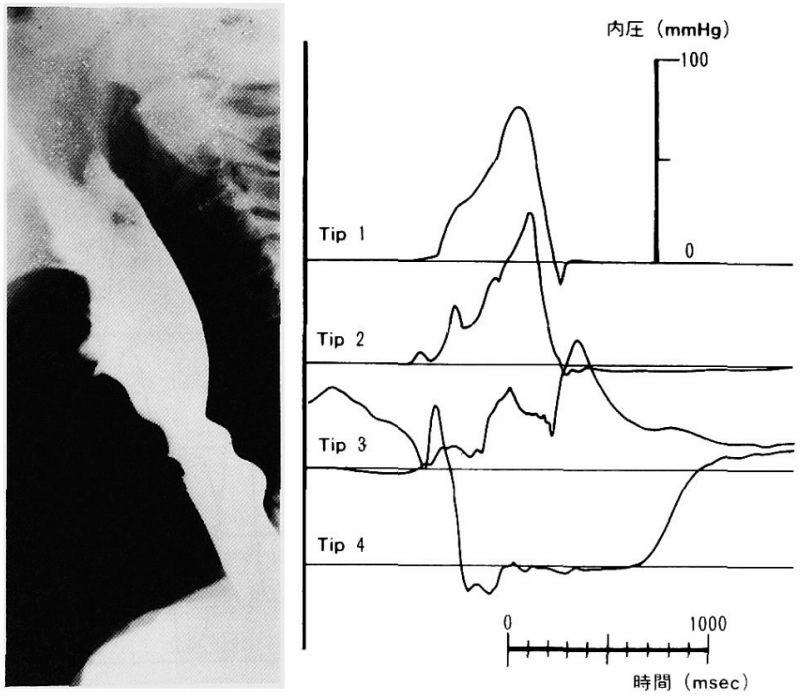

S.S. 66歳 男性

$\mathrm{C}_{4-5}$ Stage IV

$\mathrm{C}_{5-6}$ Stage II

図 3 症例 3 の嚥下圧波形

咽頭クリアランスは須崎の分類で $\mathrm{A}+\mathrm{A}^{\prime}$ タイプを示した. 嬩下圧検査で はTip 3 の最大嚥下圧值が有意に低下し, Tip 3 で異常な嬩下圧波形を 認めた。 
食道造影検査上 10 例中 3 例に造影剂の気管内流入を認 め潜在的な嚥下機能の障害が示唆された.この 3 例の 咽頭クリアランス能は $\mathrm{A}+\mathrm{A}^{\prime}$ タイプで, 噯下圧検査 は中 - 下咽頭の嶼下圧低下や異常曣下圧波形の出現を 認めた。また対象症例の咽頭クリアランス能と嚥下圧 検査の結果を通覧すると, 咽頭クリアランス能が $\mathrm{A}+$ $\mathrm{A}^{\prime}$ タイプを示した症例では骨棘より頭側の嬩下圧值 が有意に低下し，Bタイプを示した症例では骨棘より 頭側の嶼下圧值が上昇する傾向にあった。このことか ら骨棘に伴う嬹下機能の変化としては，骨棘による物 理的な圧迫に対してょり頭側の咽頭収縮力が亢進し良 好な咽頭クリアランス能が保持される場合と, 骨棘よ り頭側の咽頭収縮力の低下や異常嬩下圧波形の出現に よって咽頭クリアランス能が悪化する場合があり，鯃 下障害の発症には後者が大きく関与していると考えら れた.

Zerhouni ら ${ }^{16)}$ は, 頸椎に異常を認めた症例の嚥下 動態を高速度映画撮影法で検討し，㖟下障害を訴えた
症例では, 舌骨・喉頭の挙上障害と咽頭蠕動波の異常 が認められたとし，骨棘による物理的な圧迫は咽頭機 能によって代償され得るが，この代償機能が障害され た場合に嶼下障害が発症すると報告している.従って, 今回の輿下圧検査で見られた咽頭収縮力の亢進は咽頭 の代償機能を反映し，咽頭収縮力の低下は代償機能の 障害を反映している所見と考えられる。こうした代償 機能を障害する要因の 1 つとしては，骨棘を基盤とし た嬩下運動の摩擦による咽頭・食道壁の炎症性変化や 炎症に伴う咽頭・食道腔の局所的な固着などが指摘さ れている ${ }^{17)} し か し$ 自験例では組織学的な検討を実施 していないため，代償機能を障害する要因として局所 的な炎症が存在するか否かは不明である。また，今回 は軽微な骨棘形成が30歳代から認められることを考慮 して全く骨棘形成の認められない成人を嶼下圧值の正 常コントロールとしたが，骨棘は高齢者に多く認めら れる変化であるため, 今後は加歯自体に伴う嚥下機能 の変化も合わせて検討する必要がある。

\section{内圧 波 形}

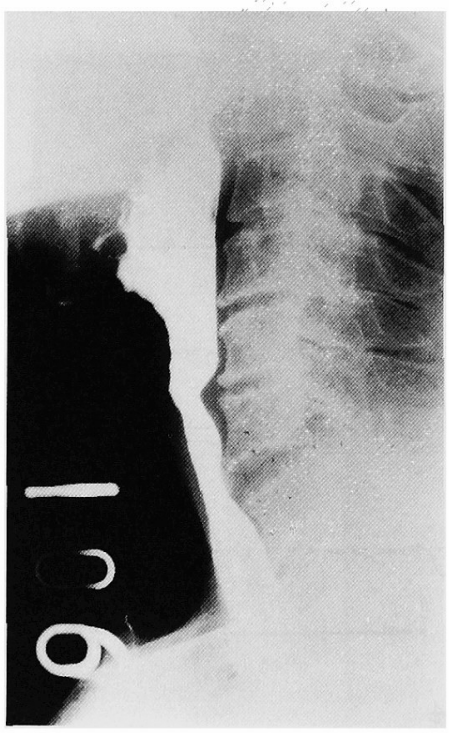

I.S. 67 歳 男性

$\mathrm{C}_{5-6}$ Stage III $\mathrm{C}_{4-5}$ Stage II

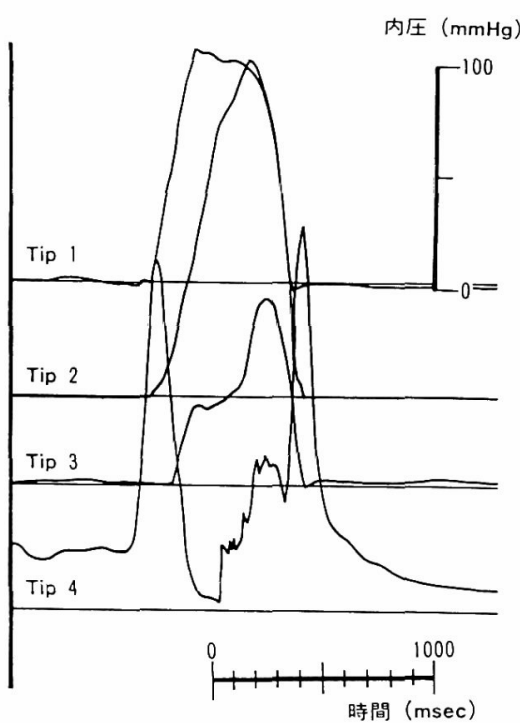

時間 (msec)

図 4 症例 6 の嚥下圧波形

咽頭クリアランスは須崎の分類で $\mathrm{A}+\mathrm{A}^{\prime}$ タイプを示した。嚥下圧検査で は Tip 2 で最大嚥下圧値の有意な上昇を認めたが，Tip 4 で食道入口部 の異常な嚥下圧波形を認めた。 
骨棘は，古くから異常感の局所的原因の1つとして 指摘されている。しかし，骨棘自体は比較的高頻度に 認められる椎骨の加榆性変化で全く無症状の場合も多 く異常感との因果関係は明確にされていない. 従って 骨栜以外に明らかな原因を認めない場合に，漠然と異 常感の原因として指摘されていることが多い. そこて

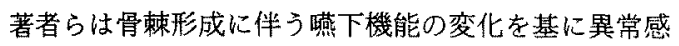
との関連を考察してみた。

稻木 ${ }^{24)}$ は異常感を訴える患者で下咽頭から頸部食 道にかけて與下压值が元進していることを指摘し，下 咽頭収縮筋および頸部食道筋の過緊張が異常感の発現 に関与していると報告している。また Wilson ら ${ }^{25)} も$ 曖下圧検查上, 下部食道高圧帯, 上部食道高圧帯, 及 び食道の連動に有意差はないが, 異常感を訴える症例 では咽頭収縮波と曂下後の静止圧が上昇したと報告し ている。こうした咽頭収縮力の艺進するメカニズムと しては, それより尾側の器質的・機能的狭窄の存在が 考えやすいがその詳細は明らかにされていない24. し かし，自験例では明らかな骨棘を認めた症例を対象と

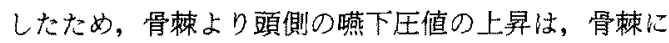
よる咽頭・食道腔の物理的圧迫（器質的狭窄）に対す る代償的な咽頭収縮力の元進を示している，従ってこ うした咽頭収縮力の元進が異常感の発症に関与した可 能性が示唆される。

これに対して異常感を訴える症例では咽頭クリアラ ンス能が不良になる頻度が高く，異常感の成因の1つ として曣下機能の潜在的な障害が指摘されている ${ }^{26)}$.

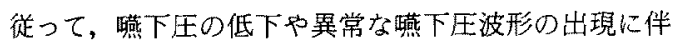
って咽頭クリアランス能が著明に障害されていた症例 では，代顀機能の低下に伴う潜在的な嚥下機能の障害 自体が異常感や與下後の残存感の発症に留与している と考えられる。

今回は明らかな骨棘形成を認めた症例に限定して異 常感との関連を検討したため，ょり軽度な骨棘の場合 を包括した結論的なことを論ずることは出来ないが， 明らかな骨棘形成を認める症例では，骨棘という器筫 的な変化を基盤とした尴下運動の異常が異常感の発症 に深く関与していると考えられる．従って明らかな骨 棘に伴う翼常感の発症は, 器質的な異常を認めない“い わゆる咽喉頭異常感症”と区別して扱うべき病態であ ろう.

\section{6. 結 語}

明らかな骨棘を認めた10例の魦下機能を咽頭二重造
影検查と噯下圧検查で検討し次の結果を得た。

1) 咽頭クリアランス能は, 須崎の分類で $\mathrm{A}+\mathrm{A}$ タイプを示した症例が 5 例B夕イブを示した症例が 5 例であった。

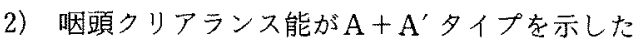

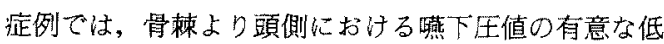
下や買常な䱏下圧波形の出現を認めた。

3）咽頭クリアランス能がB夕イプを示した症例で は，骨棘より頭側の與下值が有意に上䍙することが 多加た。

4）こうした嚥下機能の変化は，骨棘の程度と明ら かな相関関係を認めなかった。

5）骨棘を認めた10例のうち咽頭二重造影検査执上 び曣下圧検育の双方が正常であった例はなかった。

6）骨轓に伴う嶼下機能の変化には，骨棘より頭側 の咽頭収縮力が艺進し㸶頭クリアランス能が比較的良 好に保たれる場合と，因頚収縮力が低下し咽頭クリア ランス能が不良になる場合がありこうした髙下機能 の変化が咽喉頭異常感の発症に関連していると考えら 礼的。

\section{参考献}

1) Maran A, Jacobson I : Cervical osteophytes present. ing with pharyngeal symptoms. Laryngoscope 81 : 412-417, 1969.

2) Wellen PV, Klaes R, Boeck H: Hypertrophic Cervical Osteophytes Presenting with Pharyngeal Symptoms. Acta Orthopadica Belgica 55: 599$603,1989$.

3）井上鐵三，田中英一：咽㘈頭異常感症と頸椎異常. JOHNS 5: 1107-1109, 1989.

4) Nathan $\mathrm{H}$ : Osteophytes of the vertebral column. J Bone Joint Surg 44-A : 243-268, 1962.

5）須㱦一雄：咽頭の神経・筋買常の簡便X線検查法の試 双. 臨床放射線 28:427-430，1983.

6) 玄 奉学: 頸椎椎間板 0 臨床病理学的研究一第 2 編； 形態学的・X線学的所見について一日整会誌 64 : 572-582, 1990.

7) Forestier J, Rotes-Querol J: Senile ankylosing hyperostosis of the spine. Ann Rheum Dis $9: 321-330,1950$.

8) Lackner VJ: Die Forestiersche Erkrankung der Wirbelsâule. Fortschr Röntgenstr 91: $71-76$, 1959.

9) Parker MD: Dysphagia due to Cervical Osteo- 
phytes: A Controversial Entity Revisited. Dysphagia $3: 157-160,1989$.

10）江崎季夫, 森川有朗, 前山忠翤, 前原法文, 進 武幹: 輏下障害をきたしたForestier 病の1例。耳鼻 36 ： 1047-1050, 1990.

11) Lambert JR, Tepperman PS, Jimenez J et al : Cervical Spine Disease and Dysphagia -Four New Cases and a Review of the Literature. Am J Gastroenterology $76: 35-40,1981$.

12) Sobol SM, Rigual NR : Anterolateral extrapharyngeal approach for cervical osteophyte induced dysphagia. Literature Review. Ann Otol Rhinol Laryngol 93:498-504, 1984.

13) Brandenberg G, Leibrock LG: Dysphagia and Dysphonia Secondary to Anterior Cervical Osteophytes. Neurosurger 18:90-93, 1986.

14）井上鐵三，沢田政道，渡辺英男，鈴木 博：Forestier 氏病と暖下障害。日耳覺 $80 ： 1213-1215 ， 1977$.

15) Bone RC, Nahum AM, Harris AS : Evaluation and Correction of Dysphagia-Producing Cervical Osteophytosis. Laryngoscope 84: 2045-2050, 1974.

16) Zerhouni EA, Bosma JF, Donner MW : Relationship of Cervical Spine Disorders to Dysphagia. Dysphagia 1:129-144, 1987.

17) Hargrove MD: Dysphagia associated with inflammatory reaction within the esophagus at the level of a vertebral spur. Gastrointestinal Endoscopy $13: 28-29,1966$.

18）岩鴄恵美子, 菊池尚子, 白幡裕子：Forestier 病に由来 した䠢下障害の 1 治療例。日気食会報 $26: 28-32$,
1975.

19) Crowther JA, Ardran GM: Dysphagia due to cervical spondylosis. J Laryngology and Otology 99 : 1167-1169, 1985.

20) Umerah BC, Mukherjee BK, Ibekwe O: Cervical spondylosis and dysphagia. J Laryngology and Otology $95: 1179-1183,1981$.

21）須崎一雄, 寺山吉彦, 田中克彦：咽㬋頭異常感のX線煏 断一機能検查法 $\sigma$ 考案と応用一耳鼻臨床 補 $23: 55$ 61, 1988 .

22）稲木匠子, 丘村 熙, 森 敏裕：食道透視と圜下圷測定 上りみた咽喉頍異常感の㱬下機能. 耳鼻臨床 補23: $40-45,1988$.

23）森 敏裕，丘村 熙：睘下圧曲線よりみた嬩下障害の 分類の訪み.日気食会報 $36: 363-370 ， 1985$.

24）稲木匠子：咽喉頭異常感症に坊ける潜在的睘下異常の 研究：下咽顕・頚部食道過緊張症の提唱。日耳鼻 94 ： 1234-1243, 1991

25) Wilson JA, Pryde A, Piris J et al: Pharyngoesophageal Dysmotility in Globus Sensation. Arch Otolaryngol Head and Neck Surg 115 : 1086-1090, 1989.

26) 稲木匠子, 丘村 熙, 森 敏裕: Computed Radiography (CR)に上万咽頭二重造影法一と々に㸶喉䫒賽常感

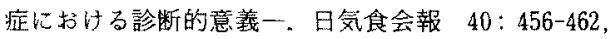
1989.

(1992年6月22日受稿 1992 年11月 5 日受理)

別刷請求先 干359 埼玉県所沢市並木3-2

防衛医科大学校耳悬咽喉科学教室 大前由紀雄 


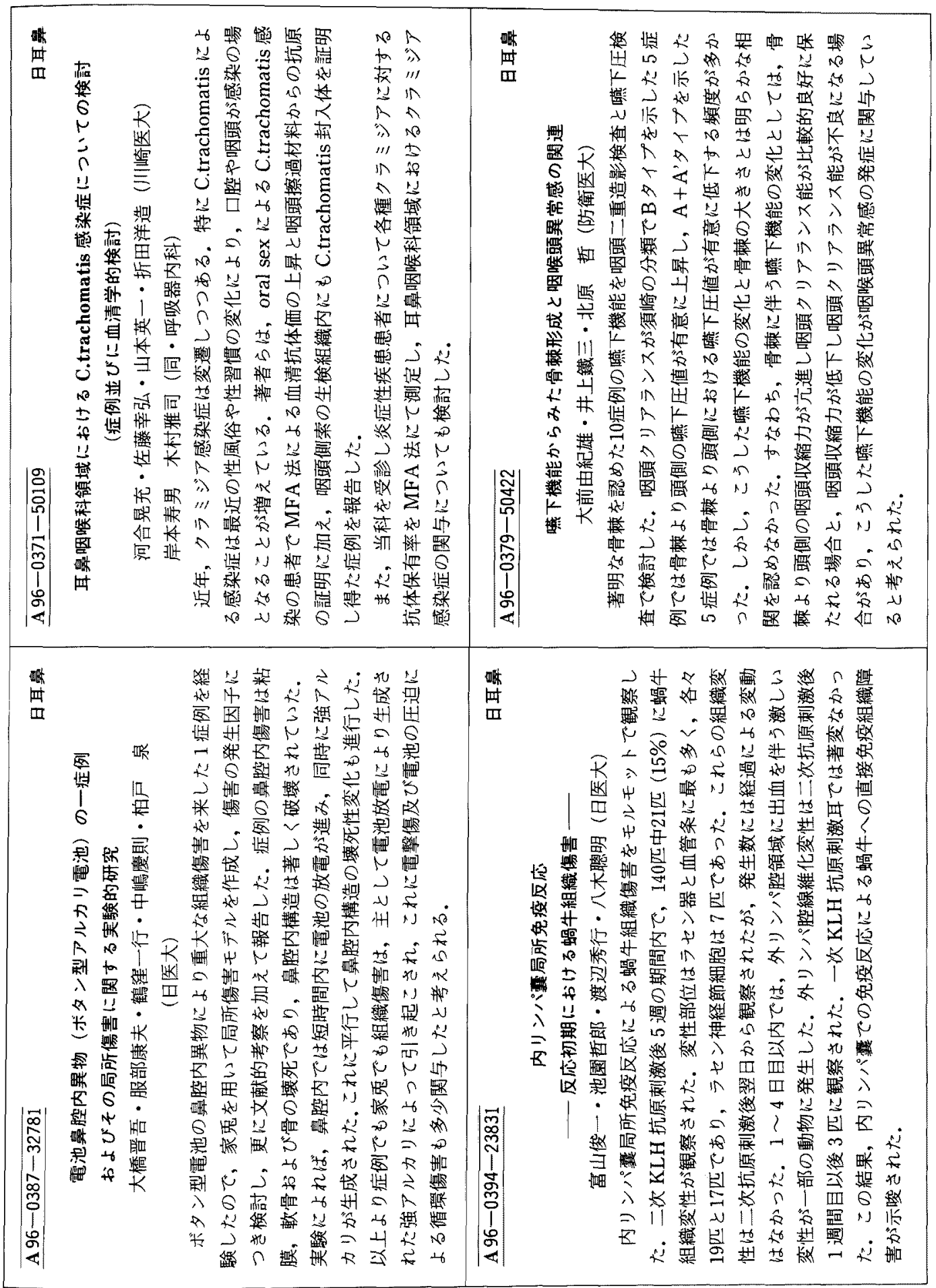

